Perbedaan hasil belajar siswa dengan menggunakan Strategi pembelajaran pada siswa smk negeri 1 Tanjung morawa deli serdang

\title{
PERBEDAAN HASIL BELAJAR SISWA DENGAN MENGGUNAKAN STRATEGI PEMBELAJARAN PADA SISWA SMK NEGERI 1 TANJUNG MORAWA DELI SERDANG
}

\section{Dr. Baharuddin}

\section{baharuddin.bah@gmail.com}

\begin{abstract}
ABSTRAK
Penelitian ini bertujuan untuk mengetahui perbedaan hasil belajar Pengaturan Motor Mekanik yang dibelarkan dengan Strategi Pembelajaran Problem Based Learning siswa kelas X TeknikTenaga Listrik SMK Negeri 1 Tanjung Morawa Deli Serdang.

Penelitian ini dilakukan pada siswa kelas X Teknik Tenaga Listrik. Populasi penelitian ini adalah peserta didik kelas X TTL yang berjumlah 74 orang. Teknik pengambilan sampel digunakan dengan cara teknik random, dimana yang terpilih sebagai kelas eksperimen yang menggunakan Strategi Pembelajaran Problem Based Learning) kelas X TTL 1 yang berjumlah 37 siswa, sedangkan yang terpilih sebagai kelas kontrol adalah yang menggunakan Strategi Pembelajaran Ekspositori kelas X TTL 2 yang juga berjumlah 37 siswa.

Metode penelitian yang digunakan pada penelitian ini adalah penelitian eksperimen. Teknik pengumpulan data dijaring dengan menggunakan tes. Teknik analisis data yang digunakan adalah validitas test, indeks kesukaran soal, reliabilitas test. Hasil belajar siswa yang belajarkan dengan menggunakan Strategi Pembelajaran Problem Based Learning memiliki skor rata-rata 24.027 sedangkan dengan menggunakan Strategi pembelajaran Ekspositori memiliki skor rata-rata 16,648. Uji statistik dengan menggunakan uji-t diperoleh $t_{\text {hitung }}>t_{\text {tabel }}$ yaitu 13.8>1.7, disimpulkan bahwa hasil belajar siswa yang dibelajarkan dengan menggunakan Strategi Pembelajaran Problem Based Learning lebih tinggi dibandingkan dengan hasil belajar siswa yang dibelaajarkan dengan menggunakan Strategi Pembelajaran Ekspositori di kelas X SMK Negeri 1 Tanjung Morawa
\end{abstract}

\section{Kata Kunci : Problem Based Learning, Ekspositori, Hasil Belajar}

\section{PENDAHULUAN}

\section{A. Latar Belakang Masalah}

Ilmu Pengetahuan Teknologi (IPTEK) saat ini telah memberikan manfaat yang banyak bagi kehidupan manusia. Perkembangan teknologi tersebut telah mencakup segala aspek kehidupan masyarakat. Seiring dengan perkembangan teknologi tersebut dibutuhkan peningkatan kualitas Sumber Daya Manusia (SDM) yang handal. Pendidikan merupakan salah satu bidang yang bertujuan untuk membentuk manusia seutuhnya yang handal dan berkompeten .

Peningkatan kualitas Sumber Daya Manusia melalui pendidikan akan menghasilkan SDM yang mampu bersaing secara sehat dalam ketatnya kompetensi dalam IPTEK. Sehingga sangat diharapkan adanya lembaga yang menghasilkan SDM yang berkompeten dibidangnya.
Sekolah merupakan salah satu lembaga pendidikan formal yang menghasilkan lulusan yang diharapkan nantinya dapat menggunakan keahliannya di IPTEK. Sekolah yang mampu menghasilkan SDM yang terampil dan berkualitas diharapkan dari Sekolah Menengah Kejuruan (SMK).

Sebagai bagian dari Sistem Pendidikan Nasional, SMK merupakan lembaga pendidikan yang mengutamakan pengembangan kemampuan peserta didik untuk dapat bekerja dalam bidang tertentu, kemampuan beradaptasi di lingkungan kerja, melihat peluang kerja dan mengembangkan diri di kemudian hari.

Proses belajar mengajar di SMK sering kali masih terdapat persoalan kurangnya pemahaman siswa tentang materi yang diajarkan, hal ini karena banyaknya siswa yang dapat menghapal atau mengingat materi dengan baik tetapi tidak mengerti 
Perbedaan hasil belajar siswa dengan menggunakan Strategi pembelajaran pada siswa smk negeri 1

Tanjung morawa deli serdang

maksud, tujuan dan konsep materi yang diajarkan, sehingga belajar menjadi kurang bermakna. Siswa dapat mengingat materi tetapi mereka tidak mampu menghubungkan atau mengkaitkan materi ajar yang mereka terima di sekolah dengan bagaimana pengetahuan tersebut akan digunakan nantinya.

Pada proses belajar atau kegiatan belajar di kelas, guru dituntut untuk dapat merangsang minat peserta didik untuk dapat belajar tanpa diperintah atau diinstruksikan terlebih dahulu. Siswa dituntut untuk lebih aktif dalam proses belajar, sedangkan peran guru sebagai motivator dan fasilisator dalam proses belajar tersebut. Dalam proses pembelajaran ini guru dituntut lebih kreatif dan memiliki kemampuan-kemampuan khusus dalam mengembangkan siswa. Oleh karena itu guru harus menguasai strategistrategi pembelajaran yang akan diterapkan dalam kegiatan pembelajaran dengan tujuan meningkatkan kompetensi siswa.

Perubahan cara belajar dahulu yang lebih terpusat ke guru, sekarang beralih dan terpusat ke peserta didik dengan adanya strategi pembelajaran. Sekarang guru telah lebih ditekankan untuk menguasai kompetensi pedagogik tetapi kenyataan masih banyak guru yang kurang sukses menerapkan ilmu mendidiknya untuk membelajarkan peserta didik, belum menggunakan metode-metode yang bervariasi. Dengan menggunakan cara belajar yang klasik atau proses belajar yang terpusat ke guru yaitu dengan menggunakan metode ceramah atau tanya jawab tentunya akan membuat keadaaan kelas menjadi monoton dan cenderung membosankan, apalagi terus diterapkan berulang-ulang selama satu semester. Oleh karena itu dengan menggunakan strategi pembelajara yang variasi diharapkan keadaan saat proses belajar di kelas akan tidak monoton. Pelaksanaan proses belajar mengajar guru harus dapat melibatkan siswa secara aktif. Dengan demikian guru dituntut untuk menemukan alternatif starategi pembelajaran yang harus diterapkan dalam proses pembelajaran guna tercapainya tujuan pembelajaran yang optimal

Sekolah Menengah Kejuruan Negeri 1 Tanjung Morawa adalah salah satu sekolah yang memiliki Program Keahlian Teknik Tenaga Listrik (TTL). Dari survey yang dilakukan dilapangan dengan melihat hasil penilaian guru bidang studi hasil belajar siswa kelas X TTL untuk mata pelajaran Pengaturan Motor Mekanik masih dibawa Kriteria Ketuntasan Minimal (KKM) dengan nilai rata-ratanya 6,5 sedangkan untuk standar nilai KKM yang ditetapkan adalah diatas 7,0.

Hasil tanya jawab kepada guru bidang studi TTL di SMK Negeri 1 Tanjung Morawa tentang masalah belajar yang dihadapi siswa di dalam kelas dikemukakan beberapa masalah yang salah satunya adalah kurangnya keaktifan belajar siswa sehingga pembelajaran tidak berjalan dengan lancar dan optimal. Hal inilah yang menyebabkan rendahnya hasil belajar siswa.

Rendahnya hasil belajar siswa sering dikaitkan dengan cara guru mengajar. Dimana guru Program Keahlian TTL di SMK Negeri 1 Tanjung Morawa menyampaikan pelajaran masih menggunakan strategi pembelajaran Ekspositori. Pada strategi pembelajaran Ekspositori, guru berdiri di depan kelas mendominasi semua kegiatan belajar mengajar di sekolah. Siswa hanya sebagai penerima pelajaran dengan cara pasif. Proses ini hanya menekankan pada pencapaian tuntutan kurikulum dan penyampaian tekstual semata dari pada pengembagan kemampuan belajar siswa. Keterlibatan siswa selama pembelajaran belum optimal sehingga berakibat pada perolehan hasil belajar siswa tidak optimal pula. Disini peran siswa tidak lagi sebagai subyek belajar melainkan sebagai obyek pembelajaran. Tanggung jawab siswa terhadap tugas belajarnya seperti dalam hal kemampuan mengembangkan, menemukan, menyelidiki, dan mengungkap pengetahuan yang dimiliki masih sangat kurang.

Proses pembelajaran seperti ini berdampak pada pencapaian belajar 
Perbedaan hasil belajar siswa dengan menggunakan Strategi pembelajaran pada siswa smk negeri 1

Tanjung morawa deli serdang

sebagian siswa SMK Negeri 1 Tanjung Morawa yang belum mencapai kriteria ideal sesuai ketuntasan yang ditetapkan. Ketidak tercapaian ketuntasan belajar disebabkan karena siswa kurang mampu menyelesaikan permasalahan sesuai tahapan penyelesaian soal berbentuk masalah. Pola pengajaran yang selama ini digunakkan guru belum mampu membantu siswa dalam menyelesaikan soal-soal berbentuk masalah, mengaktifkan siswa dalam belajar, memotivasi siswa untuk mengemukakan ide dan pendapat mereka dan bahkan siswa masih enggan untuk bertanya pada guru jika mereka belum paham terhadap materi yang disajikan guru. Disamping itu juga, guru senantiasa dikejar oleh target waktu untuk meyelesaikan setiap pokok bahasan tanpa memperhatikan kompetensi yang dimiliki siswanya.

Guru hendaknya mampu menerapkan suatu strategi pembelajaran yang dapat meningkatkan kemampuan siswa dalam mengembangkan, menemukan, menyelidiki, dan mengungkap ide siswa sendiri serta melakukan proses penilaian yang berkelanjutan untuk mendapatkan hasil belajar siswa yang optimal.

Salah satu strategi pembelajaran yang dapat membantu siswa memecahkan masalah adalah strategi pembelajaran ProblemB ased Learning (PBL). Strategi ini merupakan pendekaatan pembelajaran siswa pada masalah autentik sehingga siswa dapat menyusun pengetahuannya sendiri, menumbuh kembangkan keterampilan yang tinggi dan inkuiri, memandirikan siswa, dan meningkatkan kepercayaan dirinya. Dalam strategi ini peran guru adalah mengajukan masalah, mengajukan pertanyaan, memberikan kemudahan suasana berdialog, dan memberikan fasilitas serta melakukan penelitian.

\section{B. Kajian Pustaka}

\section{Hakikat Hasil Belajar}

Slameto (2003: 2) yang mendefenisikan bahwa belajar adalah suatu proses usaha yang dilakukan seseorang untuk memperoleh suatu perubahan tingkah laku

yang baru secara keseluruhan sebagai hasil pengalamannya sendiri dalam interaksi dengan lingkungannya. Rusman (2012: 1) belajar adalah proses interaksi terhadap semua situasi yang ada disekitar individu. Selanjutnya Sanjaya (2006: 112) bahwa belajar adalah proses mental yang terjadi di dalam diri seseorang, sehingga menyebabkan munculnya perubahan tingkah laku. Berdasarkan pengertian di atas dapt dimpulkan belajar adalah proses perubahan karena interaksi yang dilakukan seseorang terhadap situasi disekitarnya sehingga menyebabkan perubahan pengetahuan, sikap, dan kebiasaannya sebagai hasil dari pengalaman dalam interaksi tersebut.

Usaha untuk mencapai perubahan tingkah laku tersebut adalah proses belajar, sedangkan perubahan tingkah laku adalah hasil belajar. Menurut Sudjana (2009: 22) hasil belajar adalah kemampuankemampuan yang dimiliki siswa setelah ia menerima pengalaman belajarnya. Hasil belajar sering juga disebut prestasi yang kemudian di dalam bahasa Indonesia diartikan sebagai hasil usaha. Prestasi banyak digunakan dalam berbagai bidang dan diberi pengertian sebagai kemampuan, keterampilan, dan sikap seseorang dalam menyelesaikan sesuatu hal.

\section{Hakikat Strategi Pembelajaran Problem-} Based Learning (PBL)

Menurut Sanjaya (2006: 126) yang mengemukakan bahwa strategi pembelajaran merupakan rencana tindakan (rangkaian kegiatan) termasuk penggunaan metode dan pemanfaatan berbagai sumberdaya/kekuatan dalam pembelajaran.Yamin (2013: 7) strategi pembelajaran berkenaan dengan pendekatan pembelajaran sebagai suatu cara yang sistematik dalam mengkomunikasikan isi pelajaran kepada pebelajar untuk mencapai tujuan pembelajaran. La Iru (2012: 6) juga menyebutkan bahwa strategi pembelajaran adalah acuan pembelajaran yang dilaksanakan berdasarkan pola-pola pembelajaran tertentu secara sistematis.Sehingga berdasarkan beberapa 
Perbedaan hasil belajar siswa dengan menggunakan Strategi pembelajaran pada siswa smk negeri 1

Tanjung morawa deli serdang

pendapat di atas, dapat disimpulkan bahwa strategi pembelajaran adalah pola-pola pembelajaran yang dibentuk sebagai acuan pembelajaran yang dapat digunakan untuk merancang bahan-bahan pembelajaran dan membimbing pembelajaran di kelas.

Sanjaya (2006: 214) mendefinisikan Problem-based Learning (PBL) sebagai rangkaian aktivitas pembelajaran yang menekankan kepada proses penyelesaian masalah yang dihadapi secara ilmiah. Yamin (2013: 62) yang menyatakan bahwa PBL merupakan salah satu model pembelajaran inovatif yang memberi kondisi belajar aktif kepada peserta didik dalam kondisi dunia nyata. Tan dalam Rusman (2012: 232) menyatakan $\mathrm{PBL}$ merupakan penggunaan berbagai macam kecerdasan yang diperlukan untuk melakukan konfrontasi terhadap tantangan dunia nyata, kemampuan untuk menghadapi segala sesuatu yang baru dan kompleksitas yang ada. Sehingga berdasarkan beberapa pendapat di atas dapat dimpulkan bahwa PBL adalah pembelajaran siswa yang aktif dalam penyelesaian masalah yang dihadapinya sesuai kondisi dunia nyata dengan menggunakan berbagai macam kecerdasan yang diperlukan.

Yamin (2013: 81) strategi pembelajaran PBL adalah menyodorkan masalah kepada peserta didik untuk dipecahkan secara individu atau kelompok, strategi ini pada intinya melatih keterampilan kognitif peserta didik, terbiasa dalam pemecahan masalah, mengambil keputusan, menarik kesimpulan, mencari informasi, dan membuat artefak sebagai laporan mereka. Kegiatan siswa dalam Problem Based Learning (PBL) antara lain : (1).menyadari Masalah,(2). merumuskan masalah (3). merumuskan hipotesis (4) mengumpulkan data, (5). Mengumpulkan data, (6).menguji hipotesis, (7).menentukan pilihan penyelesaian

\section{Hakikat Strategi Pembelajaran Ekspositori}

Strategi pembelajaran ekspositori adalah strategi pembelajaran yang menekankan kepada proses penyampaian materi secara verbal dari seorang guru kepada sekelompok siswa dengan maksud agar siswa dapat menguasai materi pelajaran secara optimal. La Iru (2012: 41) mengatakan bawa strategi pembelajaran ekspositori adalah strategi pembelajaran yang lebih berorientasi pada guru dalam arti bahwa semua pesan pembelajaran yang diharapkan untuk dikuasai oleh siswa telah diolah dalam bentuk barang jadi oleh guru dan selanjutnya disampaikan pada siswa. Berdasarkan pendapat di atas terdapat beberapa karakteristik strategi pembelajaran ekspositori. Pertama, ekspositori dilakukan dengan cara menyampaikan materi pelejaran secara verbal artinya bertutur secara lisan yang merupakan alat utama dalam melakukan strategi ini. Oleh karena itu strategi ekspositori ini diidentikkan dengan ceramah. Kedua, biasanya materi pelajaran yang disampaikan adalah materi pelajaran yang sudah jadi seperti data atau fakta, konsep-konsep tertentu yang harus dihafal sehingga tidak menuntut siswa untuk berfikir ulang. Ketiga, tujuan utama pembelajaran adalah penguasaan materi pelajaran itu sendiri artinya setelah proses pembelajaran berakhir siswa diharapkan dapat memahaminya dengan benar dengan cara dapat mengungkapkan kembali materi yang telah diuraikan.

Proses pembelajaran ekspositori, sebelum pembelajaran berlangsung, guru mempelajari materi pelajaran dari berbagai sumber yang ada, kemudian melakukan langkah-langkah sebagai berikut: (1).guru menjelaskan materi pelajaran secara rinci kepada siswa, (2).Siswa di bawah bimbingan guru menyimpulkan materi pelajaran tersebut, (3).Siswa diminta mencatat materi pelajaran dan atau mempelajarinya kembali di rumah masingmasing.

Dari uraian di atas dapat disimpulkan bahwa dalam strategi ekspositoriini dilakukan melalui metode ceramah, namun tidak berarti proses penyampaian materi tanpa tujuan pembelajaran. Karena itu sebelum strategi ini diterapkan terlebih dahulu guru harus merumuskan tujuan pembelajaran secara jelas dan terukur.Hal 
Perbedaan hasil belajar siswa dengan menggunakan Strategi pembelajaran pada siswa smk negeri 1 Tanjung morawa deli serdang

ini sangat penting untuk dipaham, karena tujuan yang spesifik memungkinkan untuk bisa mengontrol efektivitas penggunaan strategi pembelajaran.

\section{METODE PENELITIAN}

1) Lokasi dan Waktu Penelitian

Penelitian ini dilaksanakan di SMK

Negeri 1 Tanjung Morawa dan dilakukan pada tahun ajaran 2012/2013.

2) Populasi dan Sampel

Populasi dalam penelitian ini adalah siswa kelas X TTL SMK Negeri 1 Tanjung Morawa yang terdiri dari 2 kelas dengan jumlah siswa 74 orang. Pengambilan sampel kelas eksperimen (X TTL 1) diterapkan dengan menggunakan strategi pembelajaran Problem Based Learning (PBL). Kelas kontrol (X TTL 2) diterapkan pembelajaran dengan menggunakan strategi pembelajaran ekspositori dengan masing-masing berjumlah 37 orang.

3) Variabel Penelitian

Variabel dalam penelitian variable Problem-Based Learning, Pembelajaran Ekspositori dan hasil belajar

\section{4) Definisi Operasional}

(a) Strategi pembelajaran Problem Based Learning (PBL) adalah salah satu strategi pembelajaran yang mengembangkan keterampilan berpikir dan ketermpilan mengatasi masalah, mempelajari peran-peran orang dewasa dan menjadi pelajar yang mandiri. (b).Strategi pembelajaran ekspositori adalah strategi pembelajaran yang lebih berorientasi pada guru dalam arti bahwa semua pesan pembelajaran yang diharapkan untuk dikuasai oleh siswa telah diolah dalam bentuk barang jadi oleh guru dan selanjutnya disampaikan pada siswa. (c).Hasil Pengaturan Motor Mekanik secara mekanik.

5) Jenis dan Desain Penelitian

Penelitian ini bersifat penelitian eksperimen, yang melibatkan dua variabel yaitu variable eksperimen diberlakukan pembelajaran menggunakan strategi pembelajaran Problem Based Learning (PBL) dan kelas kontrol menggunakan strategi pembelajaran Ekspositori. Akhir eksperimen ini diharapkan akan mendapat informasi tentang pengaruh terhadap hasil belajar pada mata pelajaran Pengaturan Motor Mekanik di SMK Negeri 1 Tanjung Morawa.

\begin{tabular}{l|c|c|}
\multicolumn{3}{c}{ Tabel.1 Desain Penelitian } \\
\cline { 2 - 3 } & Perlakuan & Post test \\
\hline & $\mathrm{X}_{1}$ & $\mathrm{~T}_{\mathrm{B}}$ \\
\hline & $\mathrm{X}_{2}$ & $\mathrm{~T}_{\mathrm{B}}$ \\
\hline
\end{tabular}

\section{Teknik dan Alat Pengumpul Data}

Test yang digunakan untuk memperoleh data hasil belajar siswa. Validitas butir test digunakan korelasi point biserial (rpbis), sedangkan reliabilitas menggunakan KR-20. Rumus KR-20 digunakan karena masing-masing butir soal memiliki tingkat kesukaran yang relatif sama.

Setelah data hasil belajar kedua kelompok diperoleh maka dilakukan analisis data untuk mengetahui perbedaan kedua kelompok tersebut. Untuk mengetahui apakah rata-rata dan perbedaan hasil belajar kedua kelompok, maka dilakukan analisis statistik yaitu:a). uji normalitas b). uji homogenita c). pengujian hipotesis (Uji t)

\section{E. HASIL DAN PEMBAHASAN}

Hasil penelitian meliputi data hasil eksperimen dan pengolahan data untuk teknik pengumpulan data (analisis data instrument penelitian) serta teknik analisis data.

Pada tahapan penelitian, kedua sampel yaitu kelas eksperimen dan kelas kontrol diterapkan Strategi pembelajaran yang berbeda dimana pada kelas eksperimen diterapkan Strategi Pembelajaran Problem 
Perbedaan hasil belajar siswa dengan menggunakan Strategi pembelajaran pada siswa smk negeri 1 Tanjung morawa deli serdang

Based Learning (PBL) sedangkan pada kelas kontrol diterapkan Strategi Pembelajaran Ekspositori. Diakhir penelitian pada kedua kelas diberikan instrument tes berupa pilihan berganda yang berjumlah 34 soal untuk mengetahui hasil belajar siswa setelah melalui proses pembelajaran.

Berdasarkan tes hasil belajar yang diberikan setelah proses pemberian perlakuan, skor yang diperoleh siswa pada kelas eksperimen yang dibelajarkan dengan menggunakan Strategi Pembelajaran Problem Based Learning (PBL) dapat dilihat pada tabel berikut.

Tabel.2 Data Hasil Belajar Pengaturan Motor Mekanik
Pada Kelas Eksperimen
\begin{tabular}{|c|c|}
\hline Nilai Statistik & $\mathrm{X}_{\mathrm{PBL}}$ \\
\hline $\mathrm{N}$ & 37 \\
\hline Jumlah Nilai & 889 \\
\hline Rata-rata (M) & 24,03 \\
\hline Skor Tertinggi & 27 \\
\hline Skor Terendah & 17 \\
\hline Standart Deviasi (SD) & 2,254 \\
\hline Varians & 5,082 \\
\hline
\end{tabular}

Berdasarkan data yang diperoleh dari hasil penelitian dengan jumlah responden 37 siswa terdapat skor tertinggi $=27$ dan skor terendah $=17$, dengan rata-rata $(\mathrm{M})$ $=24,03$ dan standard deviasi $(\mathrm{SD})=2,254$. Dengan menggunakan teknik Sturges didapatkan banyak kelas 6, daftar distribusi frekuensi hasil belajar yang dibelajarkan dengan menggunakan Strategi Pembelajaran Problem Based Learning (PBL) dapat dilihat pada Tabel berikut:

Tabel 3. Distribusi Frekuensi Skor Hasil Belajar Siswa Yang Dibelajarkan dengan

Strategi Pembelajaran Problem Based Learning.

\begin{tabular}{|c|c|c|}
\hline Interval & $\mathbf{F i}$ & $\mathbf{f}(\%)$ \\
\hline $17-18$ & 1 & $2,70 \%$ \\
\hline $19-20$ & 1 & $2,70 \%$ \\
\hline $21-22$ & 6 & $16,22 \%$ \\
\hline $23-24$ & 13 & $35,14 \%$ \\
\hline
\end{tabular}

\begin{tabular}{|c|c|c|}
\hline $25-26$ & 11 & $29,73 \%$ \\
\hline $27-28$ & 5 & $13,51 \%$ \\
\hline Jumlah & $\mathbf{3 7}$ & $\mathbf{1 0 0 \%}$ \\
\hline
\end{tabular}

Dari tabel dapat dilihat distribusi frekuensi data hasil belajar siswa yang dibelajarkan dengan Strategi Pembelajaran Problem Based Learning (PBL). Lebih jelas dapat dilihat pada gambar berikut:

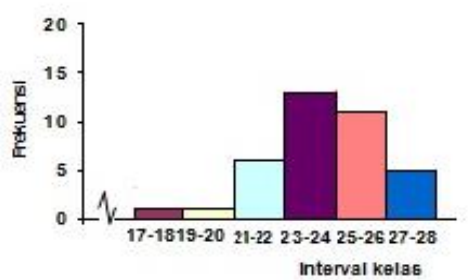

Gambar 1. Histogram Hasil Belajar Siswa Yang Dibelajarkan dengan

Strategi Pembelajaran Problem Based Learning

Sesuai dengan standar Kriteria Ketuntasan Minimal (KKM) yaitu 7,0 maka dapat disimpulkan bahwa hasil belajar siswa yang diajarkan dengan Strategi Pembelajaran Problem Based Learning (PBL) tergolong baik dengan memperoleh nilai rata-rata 24,03.

Berdasarkan tes hasil belajar yang diberikan setelah proses pemberian perlakuan, skor yang diperoleh siswa pada kelas kontrol yang diajar dengan menggunakan Strategi Pembelajaran Ekspositori dapat dilihat pada tabel berikut:

Tabel.4 Data Hasil Belajar Pengaturan Motor Mekanik Pada Kelas

\begin{tabular}{|c|c|}
\hline \multicolumn{2}{|c|}{ Kontrol } \\
\hline Nilai Statistik & 37 \\
\hline N & 616 \\
\hline Rumlah Nilai & 16,65 \\
\hline Skor Tertinggi & 25 \\
\hline Skor Terendah & 13 \\
\hline Standart Deviasi (SD) & 2,359 \\
\hline Varians & 5,56 \\
\hline
\end{tabular}

Dengan menggunakan teknik Sturges diperoleh banyak kelas 6 dan daftar distribusi frekuensi hasil belajar kelompok 
Perbedaan hasil belajar siswa dengan menggunakan Strategi pembelajaran pada siswa smk negeri 1

Tanjung morawa deli serdang

siswa yang diajar dengan menggunakan Strategi pembelajaran Ekspositori terlihat pada Tabel berikut:

Tabel 5 . Distribusi Frekuensi Skor Hasil Belajar Siswa Yang
Diajar
\begin{tabular}{|l|c|l|}
\hline Dengan Strategi Pembelajaran Ekspositori \\
\hline Interval & $\mathrm{Fi}$ & $\mathrm{f}(\%)$ \\
\hline $13-14$ & 6 & $16,22 \%$ \\
\hline $15-16$ & 13 & $35,14 \%$ \\
\hline $17-18$ & 12 & $32,43 \%$ \\
\hline $19-20$ & 4 & $10,81 \%$ \\
\hline $21-22$ & 1 & $2,70 \%$ \\
\hline $23-24$ & 0 & $0,00 \%$ \\
\hline $25-26$ & 1 & $2,70 \%$ \\
\hline Jumlah & 37 & $100 \%$ \\
\hline
\end{tabular}

Dari tabel dapat dilihat distribusi frekuensi data hasil belajar siswa yang diajar dengan Strategi Pembelajaran Ekspositori. Lebih jelas dapat dilihat pada gambar berikut:

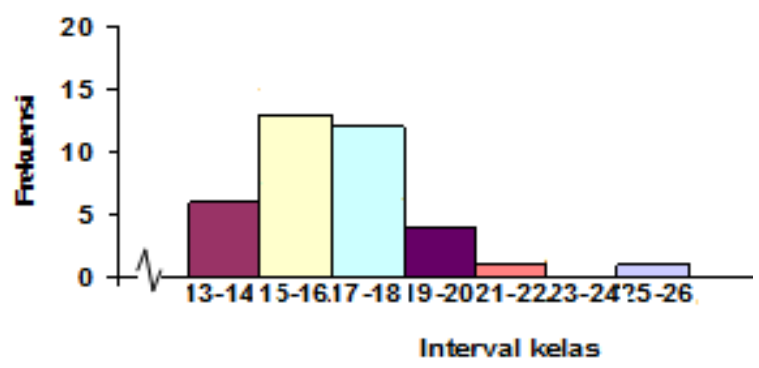

Gambar 2. Histogram Hasil Belajar Siswa Yang Diajar Dengan Strategi Pembelajaran Ekspositori

Sesuai dengan standar Kriteria Ketuntasan Minimal (KKM) yaitu 7,0 maka dapat disimpulkan bahwa hasil belajar siswa yang diajarkan dengan Strategi Pembelajaran Ekspositori tergolong rendah dapat dilihat dari nilai rata-rata yang diperoleh 16,65

Setelah diketahui bahwa untuk data hasil belajar kedua sampel berdistribusi normal dan homogen, selanjutnya dilakukan pengujian hipotesis. Pengujian hipotesis untuk hasil belajar dilakukan pada data postest dan diuji melalui uji perbedaan dua rata-rata yaitu uji-t independen. Hasil pengujian pada taraf $\alpha=0,05$ diperoleh $\mathrm{t}_{\text {hitung }}>\mathrm{t}_{\text {tabel }}$ yaitu $13,8>1,7$.

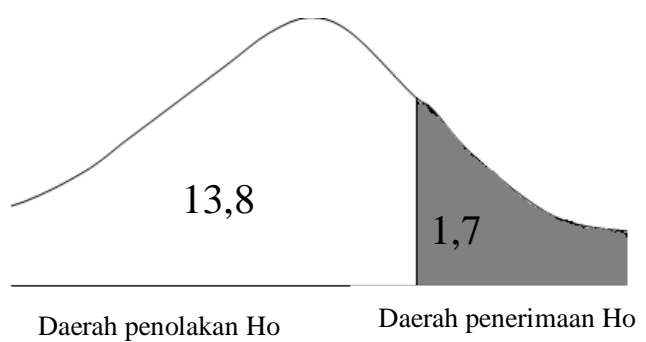

Gambar 3. Kurva Penerimaan dan Penolakan Ho Uji Hipotesis Uji $\mathrm{t}$ Independen

Dengan demikian $\mathrm{H}_{0}$ ditolak dan $\mathrm{H}_{\mathrm{a}}$ diterima yang berarti ada perbedaantegi hasil belajar pada pembelajaran Problem Based Learning pada Pengaturan Motor Mekanik.Berarti rata-rata hasil belajar siswa yang dibeljarkan dengan strategi pembelajaran Problem Based Learning lebih tinggi dari pada rata-rata hasil belajar siswa yang diajar dengan pembelajaran Pengaturan Motor Mekanik kelas X SMK Negeri 1 Tanjung Morawa T.A 2012/2013.

Hasil belajar Pengaturan Motor Mekanik dengan menggunakan strategi pembelajaran Problem Based Learning pada siswa kelas $\mathrm{X}$ bidang keahlian Teknik Tenaga Listrik SMK Negeri 1 Tanjung Morawa adalah sebesar rata-rata 24,03. Dan hasil belajar Pengaturan Motor Mekanik menggunakan strategi pembelajaran ekspositori pada siswa kelas $\mathrm{X}$ bidang keahlian Teknik Tenaga Listrik SMK Negeri 1 Tanjung Morawa T.A. 2012/2013 adalah 16,65

\section{F. Pembahasan}

Hasil belajar Pengaturan Motor Mekanik pada siswa yang dibelajarkan dengan menggunakan strategi pembelajaran Problem Based Learning (PBL) lebih tinggi dikarenakan melalui pembelajaran PBL siswa didorong untuk aktif dalam menemukan sendiri letak kesulitan dari konsep-konsep pelajaran. Melalui pembelajaran Problem Based Learning (PBL), siswa mempunyai kesempatan yang seluas-luasnya untuk menggunakan kreatifitasnya dalam belajar, sehingga 
Perbedaan hasil belajar siswa dengan menggunakan Strategi pembelajaran pada siswa smk negeri 1

Tanjung morawa deli serdang

dengan adanya kesempatan tersebut hasil belajar siswa menjadi lebih baik.

Disisi lain melalui pembelajaran ekspositori, interaksi yang terjadi hanya satu arah saja yaitu dari guru ke siswa. Pola belajar yang demikian tidak menuntut siswa untuk aktif karena proses belajar mengajar berjalan secara deskriptif serta hanya menjelaskan dan memaparkan informasi kepada siswa. Kondisi pembelajaran yang demikian merupakan penyebab mengapa hasil belajar Pengaturan Motor Mekanik pada siswa dengan pembelajaran ekspositori lebih rendah dari hasil belajar Pengaturan Motor Mekanik pada siswa yang dibelajarkan dengan pembelajaran Problem Based Learning (PBL). Dengan demikian dapat disimpulkan bahwa keunggulan pembelajaran Problem Based Learning (PBL) dari pada pembelajaran ekspositori terletak pada kemampuan strategi pembelajaran tersebut untuk menciptakan kesempatan atau pengalaman belajar yang lebih banyak kepada siswa.

Adapun hasil postes kedua kelas adalah: skor tertinggi kelas eksperimen adalah 27, skor terendah kelas eksperimen adalah 17. Skor tertinggi kelas kontrol adalah 25, skor terendah kelas kontrol adalah 13, rata-rata nilai postes kelas eksperimen adalah 24.03 dan rata-rata nilai postes kelas kontrol adalah 16.65.

Kemudian dilakukan pengujian hipotesis untuk hasil belajar dengan menggunakan uji-t. Setelah dilakukan pengujian data hasil belajar ternyata diperoleh hasil pengujian pada taraf $\alpha=0,05$ diperoleh $t_{\text {hitung }}>\mathrm{t}_{\text {tabel }}$ yaitu 13,8>1,7, maka $\mathrm{H}_{0}$ ditolak dan $\mathrm{H}_{\mathrm{a}}$ diterima. Dengan demikian dapat disimpulkan bahwa hasil belajar siswa yang dibelajarkan dengan menggunakan Strategi Pembelajaran Problem Based Learning (PBL) lebih tinggi dibandingkan dengan hasil belajar siswa yang dibelajarkan dengan menggunakan Strategi Pembelajaran Ekspositori.

Berdasarkan temuan-temuan penelitian maka dapat dikatakan bahwa hasil belajar siswa dengan menggunakan Strategi Pembelajaran Problem Based Learning

(PBL) lebih baik dari pada hasil belajar siswa yang dibelajarkan dengan strategi pembelajaran ekspositori. Hal ini membuktikan bahwa penggunaan Strategi Pembelajaran Problem Based Learning (PBL) diperlukan pada penguasan hasil belajar Pengaturan Motor Mekanik

\section{G. KESIMPULAN}

Berdasarkan hasil penelitian yang diperoleh dapat disimpulan, yaitu:

1. Hasil belajar Pengaturan Motor Mekanik kelas X SMK Negeri 1 Tanjung Morawa yang dibelajarkan dengan menggunakan Strategi Pembelajaran Problem Based Learning (PBL) lebih tinggi dari pada Strategi Pembelajaran Ekspositori dengan memperoleh skor rata-rata 24,03 dengan skor tertinggi 27 dan skor terendah 17 dan nilai rata-rata 70,66 serta telah memenuhi stándar KKM, yaitu 70,00.

2. Hasil belajar Pengaturan Motor Mekanik kelas X SMK Negeri 1 Tanjung Morawa yang dibelajarkan dengan menggunakan Strategi Pembelajaran Ekspositori lebih rendah dari pada Strategi Pembelajaran Problem Based Learning (PBL) dengan memperoleh skor rata-rata 16,65 dengan skor tertinggi 25 dan skor terendah 13 dan nilai rata-rata 48,94 serta tidak memenuhi stándar KKM, yaitu 70,00.

3. Secara statistik dengan menggunakan uji-t dimana $t_{\text {hitung }}>\quad t_{\text {tabel }}$ yaitu 13.8>1,7disimpulkan bahwa hasil belajar siswa yang dibelajarkan dengan menggunakan Strategi Pembelajaran Problem Based Learning (PBL) lebih baik dibandingkan dengan hasil belajar siswa yang dibelajarkan dengan menggunakan Strateg ipembelajaran ekspositori pada mata pelajaran Pengaturan Motor Mekanik kelas X SMK Negeri 1 Tanjung Morawa Tahun Ajaran 2012/ 2013

\section{DAFTAR PUSTAKA}

Arikunto, Suharsimi. (2012). Dasar-Dasar Evaluasi Pendidikan. Jakarta: Bumi Aksara

Daryanto. (2010). Belajar Mengajar. Bandung: Yrama Widya

La Iru. (2012). Analisis Penerapan Pendekatan, Metode, Strategi dan 
Perbedaan hasil belajar siswa dengan menggunakan Strategi pembelajaran pada siswa smk negeri 1 Tanjung morawa deli serdang

Model Pembelajaran. Yogyakarta: Multi Presindo

Nahartyo, Ertambang. (2012). Desain dan

Implementasi Riset Eksperimen.

Yogyakarta: UPP STIM YKPN

Roestiyah. (1989). Masalah-massalah Ilmu

Keguruan. Jakarta: Bina Aksara

Rusman. (2012). Model-model

Pembelajaran. Jakarta: Raja

Grafindo Persada

Sanjaya, Wina. (2006). Strategi

Pembelajaran Berorientasi Standar
Proses Pendidikan. Jakarta: Kencana Prenada Media Group

Slameto. (2003). Belajar dan Faktor-faktor yang Mempengaruhinya. Jakarta: Rineka Cipta

Slavin. (2012). Cooperative Learning.

Bandung: Nusamedia

Sudjana. (2009). Penilaian Hasil Proses Belajar Mengajar. Bandung: Remaja Rosdakarya

Yamin, Martinis. (2013). Strategi dan Metode Dalam Model Pembelajaran. Jakarta: GP Press Group 